\title{
Social Distancing, Community Quarantine and Bullets: A Critical Discourse Analysis of Pres. Rodrigo Duterte's Speeches on the War against COVID-19 Pandemic
}

\author{
Juland Dayo Salayo ${ }^{1}$ \\ ${ }^{1}$ University of Santo Tomas - Manila, Philippines
}

\begin{tabular}{|c|c|}
\hline Article Info & Abstract \\
\hline $\begin{array}{l}\text { Article history: } \\
\text { Received: } 21 \text { August } 2020 \\
\text { Revised: } 19 \text { October } 2020 \\
\text { Accepted: } 20 \text { October2020 }\end{array}$ & $\begin{array}{l}\text { Purpose: Language is essential in creating ideologies and power as a means } \\
\text { of delivering a politician's agenda. Building such power, this study } \\
\text { explored the transitivity processes and how they constructed ideological } \\
\text { frame used in the first seven speeches of the Philippine President Rodrigo } \\
\text { Roa Duterte on the precautionary measures of the government during the }\end{array}$ \\
\hline $\begin{array}{l}\text { Keywords: } \\
\text { Critical Discourse Analysis, } \\
\text { Transitivity System, } \\
\text { COVID-19, } \\
\text { Social Distancing, } \\
\text { Community Quarantine }\end{array}$ & $\begin{array}{l}\text { COVID-19 crisis. } \\
\text { Approach/Methodology/Design: Both quantitative and qualitative } \\
\text { approaches were applied in this study. The corpus of the study was } \\
\text { downloaded from the website of the Presidential Communications } \\
\text { Operations Office of the Philippine government. These consist of his first } \\
\text { seven (7) public speeches and addresses with the } 15,749 \text { total number of } \\
\text { words. } \\
\text { Findings: Guided by Halliday and Matthiessen's (2004; 2014) transitivity } \\
\text { system, it was revealed that Duterte has a total 1,371 processes with a } \\
\text { preponderance use of material, relational, and mental processes showing }\end{array}$ \\
\hline $\begin{array}{l}\text { Paper Type : } \\
\text { Research Article }\end{array}$ & $\begin{array}{l}\text { that the president's concrete action, clarity of description and emotional } \\
\text { appeal effectively delivered his agenda as a political leader in order to win } \\
\text { the present crisis. These resulted in building a connection with his audience }\end{array}$ \\
\hline $\begin{array}{l}\text { Corresponding Author: } \\
\text { Juland Dayo Salayo }\end{array}$ & $\begin{array}{l}\text { in presenting specific guidelines in addressing the health-related issues } \\
\text { including social distancing, community and home quarantine, government } \\
\text { assistance, public support and a number of warnings. Likewise, the result } \\
\text { shows that language certainly serves as a tool in shaping philosophical }\end{array}$ \\
\hline $\begin{array}{l}\text { Email: } \\
\text { jdsalayo@ust.edu.ph }\end{array}$ & $\begin{array}{l}\text { foundations to serve both the speaker and the listeners in achieving their } \\
\text { goals. } \\
\text { Practical Implications: Presenting a discourse analysis of presidential } \\
\text { speeches in a time of crisis, COVID-19. } \\
\text { Originality/value: Public discourses on the precautionary measures of the } \\
\text { government in fighting COVID-19 prove that Pres. Rodrigo Duterte's } \\
\text { Speeches power, ideologies and policies are constructed and delivered } \\
\text { through transitivity system of Halliday and Matthiessen. }\end{array}$ \\
\hline
\end{tabular}

\section{Introduction}

Language is undoubtedly an instrument to elaborate a politician's policy. Indeed, there are already numbers of political discourses which have been analysed to discover and understand the philosophical underpinnings and how the language is strategically manipulated (Quijano, 2019) because any political speech depicts any politician's agenda intensified by how the functions are presented (Schäffner, 1996; Van Dijk, 1997, cited in Quijano, 2019). 
Similarly, Dimaculangan and Dimaculangan (2018) have emphasized further that language is indeed a tool of manipulating any sort of political discourse in order to cajole the listeners or the audience, so that a politician's political agenda can be achieved by expressing his leadership tenets and his desire to build unison and cohesion with them. Their considerable great interest to political discourse analysis is highly influenced by the richness of the language that constructs a well-organized structure that politicians employ in gaining public supports contrary to the linguists and analysts whose primary goal is to look at how the politician's language materializes such support Khanya \& Hamzeloub (2014).

For the discourse enthusiasts, analysis between language and its political relation can be both "descriptive and critical". The previous has its concentration on the language use and strategies in delivering the ideologies of a politicians, while the latter's critical approach focuses on "social theories which have the quality to deal with the association between language and power, regulations as well as supremacy and instructions of discourse" (Chilton, 2003, cited in Ahmed, et al., 2014, p. 143). With that, politics is truly an arena for a politician's political, economic and social agenda to be concretized. Again, language significantly shows its worth as it accompanies the politicians' journey in achieving the success of his platforms (Remorosa, 2018) which can be attested by analysing administrative discourses from various sources in the government like the president's speeches and its interaction to the people or audience for that matter (Powell, 1999, cited in Remorosa, 2018). In similar perspectives, politicians show such intelligence and creativity in order to hide or distance themselves from such unpleasant occurrences that might affect public trust or to justify even their wrongdoings. Such language creativity appear in various linguistic techniques from a word to phrases and clauses in order to establish connection between that politician and every element that composed politics, which can possibly influence his audiences' discernment (Adetunji, 2006; Fetzer \& Bull, 2012; Reyes, 2015; Wilson, 2001, cited in Khalifa, 2018).

In connection to the investigations of language in relation to political realities, researchers in language and even in field of humanities and social sciences have developed high attention to Critical Discourse Analysis (CDA). Its relevance and advantage is that CDA tends to examine how language shows the picture of the society in as much as political inequities, social dominance and manipulations are concerned in either oral or written discourse (Ahmed, et al., 2014). In that case, CDA targets the production of consciousness that language can powerfully work in shaping society and its possible movement (Norgaard, Montoro \& Busse, 2010). Hence, ideological underpinnings, including "power, blame and responsibility" (p. 20), can be revealed. Such power, which is related to knowledge, does not impose any coercive act that produces the concept of powerful and powerless, but rather, it "plays in the use of the language and other sign systems through which meaning is communicated" (Goddard \& Carey, 2017, p. 52). 
Seeing "language as a social practice" (Fairclough \&Wodak, 1997, cited in Wodak \& Meyes, 2016, p. 5; Janks, 1997, p. 329), CDA tends to interrogate such interests that connect the positioning of text discourse to power where such positioning determines who are benefited and refuted. Fairclough (1989, 1995, cited in Janks, 1997, p. 329) discussed CDA through discourse dimensions which are present in the "the object of analysis, the process by which the object is produced and received and the socio-historical conditions that govern these processes where each dimension is analysed through text analysis (description), processing analysis (interpretation) and social analysis (explanation)." Thus, an examination of social dimensions and the language use can reveal unseen or unknown elements that comprise social, political and cultural structures and affairs (Fairclough, 1993, Luke, 1997, cited in Ahmed, et al, 2014).

While it is a fact that CDA does not, in any way, exclusively follow a particular school of thought, Systemic Functional Grammar by Halliday is the most commonly suited in CDA because of its "orientation toward context: situational, generic and ideological" and its "threedimensional approach to language: textual, interpersonal and ideational" that further provide a wider range of linguistic tools for analysis (Halliday, 1994, 2004; Wodak \& Meyer, 2001, cited in Norgaard, Montoro \& Busse, 2010, p. 70). Added to that is its characteristic to reveal the intended meaning of the discourse where the used or misused of language can bring deception (Khanya \& Hamzeloub (2014).

\section{Literature Review}

By now, literature can provide interesting critical language studies applying Halliday's transitivity. For instance, in the study conducted by Naz, Alvi \& Baseer (2012) on the political language of Benazir Bhutto, the dominance of material processes in her discourse has revealed her persona as a "lady of action" (p. 138). With the mental processes that follow, the authors have concluded Bhutto's high significance on the "emotional and physical participation of the masses" (p. 137) while mental processes influenced the audience, relational and behavioural clauses build her "soft image" (p. 138). Studying Obama's speeches, Alvi and Baseer (2011) identified that the previous American president employed highly the material clauses. Material processes are built by his encouragement to the Americans to be physically supportive to his administration. His success in the 2008 American presidential election appeared among the material clauses. While relatively low in terms of frequency and percentage, mental, relational and verbal processes also appear in his discourse: mental processes that connects to the emotion of the masses; relational processes that constructs his very appealing image among the masses.

Comparing speeches of Obama and Rouhani's speeches in the UN, it was identified that Obama and his government shows action leadership specifically opposing chemical weapons and preserving world peace. These are seen with the frequent use of material clauses. While these appear lesser in Rouhani's speech as compared to Obama's since he was in his preliminary stage of his presidency, material clauses are still the highest among the clauses he used. These are followed by relational and mental processes which allow the presidents to 
deliver their beliefs and to express their judgment, understanding, and preferences in building a connection between their ideologies with what people hope (Sharififar \& Rahimi, 2015). Another significant study was produced by Balog's (2019) critical discourse analysis using Halliday's transitivity of selected privilege speeches of the late Senator Miriam DefensorSantiago. Similar to other studies- material, relational and verbal processes were also used dominantly in most of her ideologically-constructed speeches in building power and in persuading her audience. Through material clauses, significant topics on illegal actions and women's discrimination with her recommendations were employed to address the identified problems. Through relational processes, different concepts were delineated which include her criticism to other political personalities. Reinforcing her arguments about the presented issues, she used verbal processes.

Looking at the discourse of Clinton and Trump's first televised debate, Zhang (2017) identified that all transitivity processes were used by both presidential candidates in winning the hearts of the Americans. This was done by presenting the real picture of America that time, and how the candidates could possibly protect their country and resuscitate their economy. The highest among those processes is the material, followed by relational and mental- while verbal, existential and behavioural processes were not observed as highly as the first three. While material processes were the highest in frequency, it is noted that Clinton employed more of it than her opponents sending the audience to cast their support to her with her action-packed determination to materialize her political agenda. Relational processes become a good tool for the candidate to clearly show the reality of America during that time, highlighting the economic issues and the provisions that new leadership would offer. Finally, both successfully employed mental clauses where recovery plans of the unfavourable economic situations of the two candidates were delivered through cognitive communication of their present hardships. To gain sympathy, most of the senser are I and we in order for the audience to smoothly accept their political viewpoints and agenda.

With the patterned results as far as transitivity system is concern, Wang (2010) cited Halliday that material, relational and mental processes are the most commonly used clauses. Supporting this, she stated that material process is in good position among those processes as far as the presentation of the achievement of a government is concern. This includes the present action in addressing various local and international relations; thus, it can be helpful in gaining public confidence to a certain leader. These were extracted from her analysis of Obama's presidential speeches from the viewpoint of transitivity and modality.

This present study focuses on the speeches of the Philippine President Rodrigo RoaDutertewhich he delivered in response to the threat of the newly-discovered virus, COVID-19 in the Philippines and in the rest of the world. While several studies were already conducted specifically concentrating on the critical discourse analysis (CDA) of his discourses such as Chaerunnisa \& Dewi (2019),Dacay (2018), Salvaleon (2018) and Dimaculangan and Dimaculangan (2018), it is of great interest to look at his public discourses in times of a health crisis. The researcher believes that this present study would give another perspective of Duterte's ideologies in dealing with the war against the new 
disease than his usual speeches on his controversial campaign on war against drugs which becomes his and his administration's identity aside from his other equally controversial foreign policies and international relations.

Due to COVID-19, the Philippine government has already made numbers of actions and decisions to immediately respond to this health problem such as class suspension especially in Metro Manila and the issuance of travel bans from several neighbouring countries and territories with recorded COVID-19 cases. Initially, the government included selected provinces and city from the Mainland China, Hong Kong, Macau and Taiwan. However, with the rise of the affected cases including death rates from other countries including Japan and European nations, and the recorded local transmission in the Philippines, President Duterte intensified the government measure by releasing official public addresses (refer to Table 2) highlighting social distancing and home and community quarantine, and later, a "shoot-to-die" order for those who creates public disturbance and disobedience. This was initially implemented in Metro Manila, and eventually extended in the whole island of Luzon and the some regions with high confirmed COVID-19 cases.

\section{COVID-19}

According to European Centre for Disease Prevention and Control (2020), this virus has been detected as early as December 2019 in Wuhan City, Hubei Province in China after at least 27 pneumonia cases were reported. Those cases were linked to Wuhan's Huanan Seafood Wholesale Market of fish and live animals. Having been tested positive for that novel coronavirus, affected patients have shown the following symptoms: dry cough, fever, shortness of breathing (dyspnoea) and pneumonia. From novel coronavirus, it was named later as SARS-CoV-2, the virus causing COVID-19. It was also identified that this virus can be transmitted from animals to humans through droplets, coughing or sneezing; in a more serious case, this disease can cause severe acute respiratory syndrome, kidney failure and death (McLeod, 2020).

The European Centre for Disease Prevention and Control continues the details that by January 2020, cases were also reported in some Asian countries aside from China like Japan, South Korea and Thailand. The growing number of cases has caused Wuhan City to be locked down to control human movement. Just some few weeks after, the first case outside Asia was reported; this time, it was in France and then Germany. The first had a travel history in China while the latter was related to a person who visited China. On January 30, 2020, this outbreak has been declared by the World Health Organization as a "public health emergency of international concern" (para. 8) until its declaration as world pandemic on March 11, 2020. Prior to this declaration, several Europeans countries have already reports on local transmission like Italy which has been seriously affected by the virus that caused their government to release "strict public health measures including social distancing" (para. 11). This outbreak continues to threaten and even claim lives in different countries, not only in Asia and Europe but in the Americas, Africa and Europe as well. 


\section{Research Questions}

This paper explored the language of Philippine President Rodrigo Duterte in his first few speeches delivered highlighting precautionary measures that the Philippine government imposed during the height of COVID-19 threat in the country. Specifically, this study answered the following questions:

1. What transitivity processes are observed in the speeches of President Rodrigo Duterte?

2. How do transitivity processes build Duterte's ideologies in relation to his policies against COVID-19 disease?

\section{Theoretical Framework}

Systemic Functional Grammar or Linguistics (SFG/L) by Halliday mainly focuses on the social structures or contexts of the language as the key to produce its meaning. With the social influence to the language, it becomes more functional than rule-based. Therefore, SFG/L offers more of a relational significance to maintain the participants' interaction with others, theirgoals, and their experiences needed to achieve something. This clearly values the communicative functions of the language that turns the speaker into a social man (Halliday \&Matthiessen, 2004). To stress out its social functions, the language shows the reason and the manner why the speakers use the language together with the grammatical and semantic roles that composed the parts of the language used (Fontaine, 2013). Developing this theory, Halliday formulated the basic functions of the language such as interpersonal meta-function (mood), ideational meta-function (experiential), and textual meta-function(theme) (Fawcett, n.d.; Stojičić, \& Momčilović, 2016).

Specifically, this paper is anchored to the transitivity system of Halliday and Matthiessen (2014) which is classified into six types of processes as material, relational, mental, verbal, behavioural, and existential in order to look at the experiential meaning of the texts.

(a) Material Process. This is the process of physical action or event that clearly shows what exactly happened in the clause. There are two participants involved in this process: Actor and Goal that serve as the agent and the object of the process, respectively. The actor may come in a form of either human or non-human participants. The following verbs show physical action that can be considered to be a material process: run, write, appoint, build, cook, sell, open, copy, etc.

e.g. They (Actor) build (Material) the commemorative landmark (Goal) near the town plaza (circ: location).

(b) Relational Process. This is the process of being which can either be attributive or identifying. Attributive involves two primary participants: Carrier and Attributesthese show a description, quality or characteristic of an object or subject in a clause. In contrast, Identifying shows the "identical properties of the two units" (p. 133). It also involves two participants: the Identified and the Identifier (Bustam, 2011, cited in 
Salvaleon, 2018). Verbs involved are usually in the form of "be": am, is, are, was, and were.

e.g. Attributive: The room is quite dark.

Identifying : That man is the club president. The club president is that man.

(c) Mental Process. This is the process of sensing where mental phenomena as perception (seeing), affection (feeling) and cognition (thinking). Senser and Phenomenon are the participants involved in mental process. Some of the verbs that show internal processing such as feeling or thinking are want, hate, love, understand, know, and the like.

e.g. The national secretariat (Senser) does not want (Mental) to release their position (Phenomenon).

(d) Verbal Process. This pertains to the process of oral communication (saying) to the receiver of the message. The participants involved the speaker or the source of the message is called Sayer; the recipient of the message is the Receiver while the message itself is called Verbiage. Bustam (2011, cited in Salvaleon, 2018) added that other type of verbal process is when the "Sayer is in sense of acting verbally on another direct participant with verbs as such: insult, praise, slander, abuse, and flatter." In this case, this participant will be called as Target.

e.g. Our committee chairman (Sayer) told (Verbal) us to sign the petition (Verbiage).

The speaker (Sayer) insults (Verbal) him (Target) in front of the public.

(e) Behavioural Process. This process refers to both "physiological and psychological behaviour". There is only one participant which can be considered the Behaver. Some of the common verbs that express behavioural process are smiling, crying, breathing, staring, etc.

e.g. The patient (Behaver) was coughing (Behavioural) hardly (Circ: Manner) last night (Circ: Time).

(f) Existential Process. This process is a clause that expresses something exists or happens. This is usually introduced by there followed by the verb "be" or other verbs of existence like exist, arise, come which is followed by the so-called Existent which pertains to the object that exists in the process (Bustam, 2011, cited in Salvaleon, 2018).

e.g. For this year's event, there is (Existential) huge number of participating schools (Existent) in the Metro.

Table 1 shows the summary of transitivity system by Halliday and Matthiessen (2004). This includes the process types, their category meaning and the involved participants.

Table 1: Summary of the six types of process based on Halliday \&Matthiessen's (2004) transitivity system

\begin{tabular}{lll}
\hline Type of Process & $\begin{array}{l}\text { Category } \\
\text { Meaning }\end{array}$ & Participants \\
\hline Material: & 'doing' & Actor, Goal \\
\hline
\end{tabular}




\begin{tabular}{lll}
\hline $\begin{array}{l}\text { Action } \\
\text { Event }\end{array}$ & $\begin{array}{l}\text { 'doing' } \\
\text { 'happening' }\end{array}$ & \\
\hline $\begin{array}{l}\text { Mental: } \\
\text { Perception } \\
\text { Affection } \\
\text { Cognition }\end{array}$ & $\begin{array}{l}\text { 'sensing' } \\
\text { 'seeing' } \\
\text { 'feeling' } \\
\text { 'thinking' }\end{array}$ & \\
\hline $\begin{array}{lll}\text { Relational } \\
\text { Attribution }\end{array}$ & 'being' & \\
Identification & 'attributing' & Carrier, \\
\hline Behavioral & 'identifying' & Attribute, Token, Value, \\
& 'behaving' & Identified \\
\hline Verbal & 'saying' & Behaver \\
\hline Existential & 'existing' & Sayer, Target \\
\hline
\end{tabular}

Source: Halliday \&Matthiessen's transitivity system (2004)

\section{Methodology and Procedures}

Both quantitative and qualitative approaches were applied in this study where quantitative is observed through frequency and percentage of the identified processes. On the other hand, qualitative was used descriptively on how President Rodrigo Duterte employed transitivity processes in his COVID-19-related speeches that helps create his ideologies as a political leader.

The corpus of the study was downloaded from the website of the Presidential Communications Operations Office (https://pcoo.gov.ph/transcripts/) of the Philippine government. These consist of his first seven (7) public speeches and addresses with the 15,749 total number of words. These were delivered in different days which are specified in the table below:

Table 2: Speeches of President Rodrigo Duterte on precautionary measures against COVID-

19

\begin{tabular}{lcc}
\hline \multicolumn{1}{c}{ Title of Speeches } & $\begin{array}{c}\text { Date of Delivery / } \\
\text { Publication }\end{array}$ & Number of Words \\
\hline $\begin{array}{l}\text { (S1) Opening Statement of President Rodrigo Roa Duterte } \\
\text { during the Inter-Agency Task Force Briefing on Covid-19 }\end{array}$ & March 9, 2020 & 279 \\
\hline $\begin{array}{l}\text { (S2) Public Address of President Rodrigo Roa Duterte on the } \\
\text { Coronavirus Disease 2019 (COVID-19) }\end{array}$ & March 12, 2020 & 4,483 \\
\hline $\begin{array}{l}\text { (S3) Guidance of President Rodrigo Roa Duterte on the } \\
\text { Coronavirus Disease 2019 (COVID-19) }\end{array}$ & March 16, 2020 & 5,338 \\
\hline $\begin{array}{l}\text { (S4) Message of President Rodrigo Roa Duterte to local } \\
\text { government units on the implementation of the Enhanced } \\
\text { Community Quarantine }\end{array}$ & March 19, 2020 & 1,347 \\
\hline $\begin{array}{l}\text { (S5) Message to the Nation of President Rodrigo Roa } \\
\text { Duterte on Coronavirus Disease 2019 (COVID-19) }\end{array}$ & March 24, 2020 & 1,094 \\
\hline $\begin{array}{l}\text { (S6) Nation Address Of President Rodrigo Roa Duterte on } \\
\text { Coronavirus Disease 2019 (COVID-19) Pandemic }\end{array}$ & March 30, 2020 & 1,950 \\
\hline
\end{tabular}


(S7) Nation Address Of President Rodrigo Roa Duterte on Coronavirus Disease 2019 (Covid-19) Pandemic Total Number of Words
April 1, 2020

1,285

\section{Source: Compiled by the author}

15,749

The authenticity of the transcripts was counterchecked from the available videos from the same government website. Having read the selected speeches, the researcher segmented the clauses to determine the involved processes specifically focused on experiential or ideational meta-functions according to the six types of transitivity processes: material, relational, mental, verbal, behavioural and existential. After classifying the processes, it was revealed that there is a total of 1,371 transitivity processes. This was validated by a linguist whose field of specialization is Systemic Functional Grammar.

\section{Results and Discussion}

There are a total of 1,371 transitivity processes after segmenting and identifying the clauses and processes. Like many other studies on critical discourse analysis of different speeches (Alvi and Baseer, 2011; Balog, 2019; Naz, Alvi \& Baseer, 2012; Sharififar \& Rahimi, 2015; Wang, 2010; Zhang, 2017), it was determined that President Rodrigo Duterte highly used material processes, followed by relational and mental. Frequency and percentage distribution of the processes used by the Duterte is shown in Table 3.

Table 3: Frequency and percentage distributions of transitivity processes used in President Rodrigo Roa Duterte's speech

\begin{tabular}{lcc}
\hline \multicolumn{1}{c}{ Transitivity Process } & Frequency & Percentage \\
\hline Material & 555 & $40.48 \%$ \\
\hline Relational & 364 & $26.55 \%$ \\
\hline Mental & 265 & $19.33 \%$ \\
\hline Verbal & 93 & $6.78 \%$ \\
\hline Existential & 77 & $5.62 \%$ \\
\hline Behavioral & 17 & $1.24 \%$ \\
\hline Total & $\mathbf{1 , 3 7 1}$ & $\mathbf{1 0 0 \%}$
\end{tabular}

Source: Compiled by the author

Table 3 shows the frequency and percentage distribution of transitivity processes appear in the public addresses of President Rodrigo Roa Duterte regarding the government precautionary moves against COVID-19. Segmenting and classifying all the involved clauses and processes, all the transitivity processes were used where material processes receive the highest frequency of $555(40.48 \%)$. It is followed by relational process with the frequency of 364 (26.55\%), the mental process having 265 (19.33\%); the other three, verbal, existential and behavioural, receive a relatively low frequency. Overall, those five speeches have the total frequency of 1,371transitivity processes. These data reveal that the president shows particularity to the physical actions and activities as his means of establishing power as leader and in building connection to his people. In relation to this, Liping (2014) has proven that while material, relational and mental processes are preponderance in his experiential metafunction analysis of Churchill's speech on Hitler's invasion of the U.S.S.R, their combination 
with the others: verbal, behavioural and existential processes can produce an even "powerful and persuasive" (p. 135) speech. The discussion below are the comprehensive details on the transitivity processes involved in Duterte's speeches and how these processes build his ideologies in relation to the war against COVID-19.

\section{Material Process}

Material processes are processes of 'doing' a certain action by a certain entity (Actor) who does something to other entity or entities (Goal) (Bustam, 2011). In Duterte'sspeeches, these received the highest frequency and percentage, 555 (40.48\%).In other words, these processes have high evidence of activities or occurrences that construct aphysical event. The actor physically shows tangible movements because of a certain encouragement, motivation or intention to achieve something; therefore, the actor has a certain goal to accomplish in order to essentially complete the meaning of the clause.

These physical actions and events were created mostly by him and his administration's decisions in addressing the health problem, in seeking the local government units' (LGU) support together with the law enforcers, and the Filipino people in general. Several constructs were identified that give stronger structure to his discourses such as responsive government, responsible citizenship, local government empowerment, solidarity and cooperation and a caveat to those who would disobey.

\section{Responsive Government}

Material processes evidently shaped the kind of government and leadership Duterte hasresponsive to the immediate need of the Filipinos, fair distribution of labour and services among his team, and respect to individual's duties and responsibilities. Initially, as head of the nation, Duterte started with the official statement addressing the issue as he was invoking the sanctity of his office --- to help people and his countrymen (S4) with the promise that they continue to respond to the public's needs, mobilize resource and oversee developments (S4) as they were addressing the COVID-19 pandemic challenges confronting the nation (S5). The following signal hisofficial declarations:

(1) Iam now addressing (material) the nation together with the civilian, military and police sectors --- the organizations that would count in our enforcement of the laws to protect the people of the Republic of the Philippines. (S2)

(2) I made a pronouncement last Thursday approving the placement of the National Capital Region under Community Quarantine. (S3)

(3) For this reason, pursuant to my powers as President under the Constitution and Republic Act No. 11332, I am placing the entire mainland of Luzon under [Community] Quarantine until April 12, 2020, coinciding with the entire end of Holy Week. (S3)

(4) We have resorted to this extreme measure of an Enhanced Quarantine or quarantine for Luzon, because the magnitude of the threat that we are facing calls for it. (S4) 
(5) I am addressing you once again about the problem of COVID pandemic. (S7)

Having been raised to Code Red Sublevel Two (S2), Duterte placed the entire country under a State of Public Health Emergency (S3) as the recommendations of the Department of Health Technical Advisory Group on imposing Stringent Social Distancing Measures in the National Capital Region are adopted for a period of thirty (30) days from the issuance of this Resolution (S2). With the declaration aim to minimize the contagion, community quarantine is hereby imposed in the [entirety] of Metro Manila (S3), eventually, it was expanded to the entire island of Luzon, and then to other regions with high record of confirmed COVID-19 cases. Hence, the following were suggested by the president in order to observe that social distancing: strict social distancing measures are required to be observed by their respective managements (S2) and works continue but with social distancing (tuloytuloyangtrabahoninyoperoang social distancing (S2)). To intensify this, home quarantine was imposed by the president so they could not transmit the disease (S3).Hence, going out of their home is allowed to only one representative of each family or household to buy food, medicine and other basic necessary for survival(S3). Remarkably, while people maintain physical distance from each other, the president calls to remain [strongly] united in spirit to fight this dreaded disease. (S3)

With the implementation of such orders from the president, there are a number of specific guidelines to different sectors and agencies such as the education department and the executive department when he suspended classes and work: the suspension of classes in all levels in Metro Manila is hereby extended until April 12, 2020 (S2) provided that all students shall continue to fulfil their educational requirements during the mentioned period. For the executive department, work shall be suspended (S2), while other public and private sectors' work shall be reduced with the strict observation on social distancing. However, he emphasized that all manufacturing, retail, and service establishments are advised to remain in operation during the mentioned period ( $S 2)$ except if the situations get worst with his statements: and for the businesses, pagkalumalaito(if this gets worst), you better close down your business.

Likewise, he has clear instructions given as the transportation sectors and overseas workers:

(1) Land, domestic air, and domestic sea travel to and from Metro Manila shall be suspended beginning 15, 2020 --- March 15, 2020 and to end on April 14, 2020. (S2)

(2) Mass public transports including the Light Rail Transits, the Metro Rail Transit, and the Philippine National Railways (actor) shall continue (material) in operation.

(3) The "Balik-manggagawa" Overseas Filipino Workers (OFWs) shall be allowed to travel to mainland China, except to Hubei Province, upon execution of a Declaration signifying their knowledge and understanding of the risks involved. (S2)Provided, that a health advisory pamphlet shall be handed out to the OFWs upon departure. (S2)

(4) The entry travel restrictions shall be imposed upon those travelling from countries with localized COVID-19 transmissions, except for Filipino citizens including their foreign spouse and children, if any, holders of Permanent Resident Visa. Holders of 
Permanent Resident Visa, and holders of Diplomatic Visas issued by the Philippine Government. (S2)

To effectively deliver government services to the public, he has appealed to his fellow public servants for their support by emphasizing their obligations and by giving specific tasks or directives during the pandemic not only to the Department of Health but also to other partner agencies which are directly involved in the total operations to be done by skeletal force: have to explain to the public itong (this) wherewithals ng (of) Code Red Sublevel Two (S2), have to find a way to best compensate our health workers (S3), shallissueguidelines to safeguard the welfare of workers (S2), shall issue guidelines to ensure social distancing in said public transports(S2), must put in place those who are living on daily wages, and small-medium enterprises with utmost dispatch and all feasible measures to ease the burden of the community quarantine (S3), directed the Department of Interior and Local Government) DILG and the Department of Justice (DOJ) to closely monitor the compliance of LGUs with the directives of the office and to file the necessary cases against wayward officials (S4), will have to go around ..., you utilize all vehicles of government available, just go around and maybe asking if there is somebody starving or in need of food (S3).

With the different development such as granting the president the emergency power from the Congress, he issued an order where responsibilities of the involved agencies are presented in the implementation of Bayanihan to Heal as One Act. In connection, the president promised to exercise the powers given only if those are needed especially in undertaking relevant measures to overcome and recover from the effects of the pandemic; this will be supported by the allotted 200 billion pesos for the low-income households who are greatly affected by the crisis as emergency support. Besides, the government will also provide the following to deal with the economic effects of the pandemic: recovery package, food packs, essential non-food items, medical supplies, devices and personal protective equipment not only in Luzon but also in the Visayas and Mindanao. Likewise, the government will also build, operate and accredit more medical facilities and laboratories to provide a wider testing. (S6)

To easily implement the orders of the president, he also called the attention and support of the local government units (LGUs) specifically mentioning the city and municipal mayors and the barangay captains (village chiefs). He has empowered them in implementing the imposed policies on social distancing and home quarantine in their localities when the president said, "And that is why mayors now can go ahead and issue ordina --- not really ordinances but executive orders to make the environment of their municipality more conducive to a healing process (S3); additionally, they were allowed to get access to their Quick Relief Response for its immediate implementation. His appeal to the LGUs is clearly stated especially in his fourth speech (S4); this time, there are already some warnings in case they would deviate or create their own ways in addressing the problem: "should abide by the directives of the national government when it sets abide by the directives of the whole for the good of the country and the protocols observed during the time of the lockdown." 
With those statements, the president asked the Filipinos to extend their cooperation by obeying what government suggests or orders people to do especially those which are released by the DOH or the doctors. Through his speeches, he deliberately and repeatedly mentioned the word "sundin" (obey) as one's contribution to this fight especially with to the following circumstances for their protection, for the alleviation of the suffering, and for the enforcement of public order: avoiding people, avoiding trouble with the law, prohibiting mass gatherings, and avoiding bars or nightclubs. Stating these, the president has strongly emphasized that failure to follow these implemented policies shall cause an even more serious problem as violators will be arrested and brought to prison as disobedience of authority, then acts of public disturbance. (S3). In relation to this, the Philippine National Police and the Armed Forces of the Philippines, in coordination of the Inter-Agency Task Force, shall be called upon to ensure effective and orderly implementation of the above measures. (S2) This was intensified during his sixth speech when he warned those people who are involved in malpractices during this difficult scenario like embezzlements, hoarding, and corruption as they may seriously face various cases.

With the measures that the government are doing, Filipino people were promised that President Duterte and his administration have to act (S3) as they shall make sure all the people will feel government's concern (S3) to safeguard their health, safety and well-being and to serve the citizens especially those who are serving in the frontlines (S5) the best possible way with transparency, so that the Philippines will not be driven towards chaos during this difficult time. (S4). To assure the people, it was stated that the Department of National Defense and the Department of the Interior and Local Government, with the Armed Forces of the Philippines and the Philippine National Police, are now ramping up the implementation of the National Action Plan (NAP) to reinforce the efforts of the Department of Health in containing COVID-19. (S5) On April 1's public speech, he assured that the cash assistance through the Social Amelioration Program to the poorest of the poor and other specified beneficiaries who are severely affected by the pandemic would be received as soon as possible through the DSWD.

To ease the tension of the people, the following were also promised by the president: supplies of food, water and other essentials throughout the ordeal and the extension of the financial assistance to those in the margins and the vulnerable groups (S5). This is intensified by his statement that everybody would be served and that he would not allow anyone to be left behind by the government services. In return, he appealed to people to cooperate with the emphasis that while the government is doing its best, we can more effectively contain the spread of the virus if we adopt a united approach (S3); likewise, he urged other public officials to set aside their differences and work in solidarity to overcome the pandemic (S5).

\section{Duterte's bullets}

After almost a month of community quarantine, Duterte has never escaped from his usual behaviour toward his political nemesis. Aside, from the virus that serves as invisible opponent in this kind of war, the president has called on those people who intentionally 
produce troubles like the "left" including those people who do act of discrimination and physical conflicts against the frontliners. With this, he orders the authority to detain them and in case the situations get worst, 'shoot them dead.' (S7)

Material processes are helpful in building Duterte's power initiate policies for the safety of the Filipinos as they try to appear very visible during the crisis. This authority is further proved by the active involvement of the primary government agencies to work hand-in-hand in addressing the health problem. In a similar way, he successfully connects himself to the people through his orders and appeals as their way of cooperating with the government. Like the study of Ist'anah (2014), material processes were also the most frequent processes as citizens would commonly demand for a more physical action from the actor specifically in dealing with Jakarta's unresolved problems that lessen the interest of the people about the election. Using passive clauses, the data further revealed that Indonesians urged the candidates to solidly act in order to achieve certain goals. Similarly, Kondowe (2014) established the idea that Bingurelates himself to the world by presenting both his past and future plans in a more active terms. Through linguistic feature, it is believed that the nation and its people show unity and solidarity needed to revive the trust of the citizens. In the same line thought, these processes as well are instrument in presenting the Malawi president's achievements especially in his facing the problem on food security and hunger through strong agricultural programs that build a stronger economic and political dogma.

\section{Relational Process}

Relational processes appear to be the second most used processes in Duterte's speeches with the total frequency of $364(26.55 \%)$. Most of them are expressed in making description or in characterizing the subject of the clause as Bustam (2011, p. 26) said that these processes build a relation of sameness between the involved entities (intensive, ' $x$ ' is 'a'), or defines the involved entity in terms of circumstances of location, time, and manner (circumstantial, ' $x$ ' is at ' $a$ ') or expressed that one entity owns another (possessive, ' $x$ ' has ' $a$ '). Some of the verbs used by the speeches are the following: am, is, are, has, and have. To put it simply, these process help in constructing the clarity of the presented concepts in connecting to people, events, and objects.

The common topics that he highlighted in his speeches are also the key terms which were shaped by the relational processes such as his description of COVID-19, the role and responsibility of the national and local government units (LGUs) in this time of pandemic with the support of the armed personnel and the civilians and the social distancing as human responsibility and his appreciation to the frontliners such as medical personnel.

\section{COVID-19 as Vicious Enemy}

Duterte initially described COVID-19 as serious virus that is contagious (S2). In this third speech, he defined it with a more social relevance being an emergency and an issue of people's interest that is rising day by day. Speaking of a Martial Law that people tend to connect to the community quarantine, he stated that Martial Law has human enemies, but this 
present battle, people only have one common adversary (S5) that is a vicious and invisible enemy which cannot be seen by naked eye, but is passable (S4) through human contact. Either way, we are in the fight for the lives while quarantine is in effect.

To ease the apprehension of the people, Duterte stated a little figure of COVID-19 stating that other countries have also the same condition; indeed, most of them were attacked first by the virus before it comes to the Philippines. He further compared the status of Italy with 1,000 affected people in just a day; in the country, the record is reasonably very low. However, his tone has changed when he delivered his $7^{\text {th }}$ public speech when he honestly described the kind of life people have after almost a month of quarantine: hirapnatayo(we are in difficulty), angatingsuplayhanggangdiyanlang(our supplies have limitation), in two days' time, patayka(you are dead) but he assured again the people that they have measures to sustain those services they provide.

\section{Structured Government}

In the midst of this serious health problem, Duterte has assured Filipino people that the government especially those responsible agencies and institutions are doing their best in addressing the issue and in protecting the people. This assurance was strengthened by stating that the purpose of government is to see that things are in order, and they are there to serve the people (S2) emphasizing that they have the structure (Merontayongistraktura.) which is pertaining to the Department of Health down to its regional office. Accordingly, they are already well-equipped. Besides, the all the government agencies are now in action (S5). But contrary to his $7^{\text {th }}$ speech, the president pointed that the government has enough supplies, has the money, does not have any expenses that are unnecessary and he is sure of that. Leaving the promise that people will not be alone in this fight is the reiteration that the national government is in full control as the problem is an emergency of national proportions (S4).The Congress, however, has given him 200 billion for all the expenditures during this crisis.

Strengthening the structure of the national government is the support of the local government units. Duterte started with describing these LGU officials: the barangay captain (village chief) is a person in authority. He further elaborated that they have been elected to do their responsibilities; otherwise, they will be in trouble. While he understands that the job of these officials is undoubtedly hard, there are no other ways but to implement the order being a part of the government. The city and municipal mayors are again mentioned because of their mandate to deal with the local emergencies as Duterte himself was once a city mayor; nevertheless, even if these mayors have their creative strategies in addressing this healthrelated issue, he emphasized that their actions are consistent with the national directives (S4). Completing the structure is the function of the military and the Philippine National Police. Duterte described these personnel as the soldier of the people and have the imprimatur of the civilian authorities (S2); thus, it is always the military who keep things in the country in order (S2) and to ensure the movement of every person during the next few weeks (S3). Once again, in his nation address dated March 30, 2020, he reiterated that the government is with the 
people having that power provided to him by Congress pursuant to Bayanihan Act in providing services especially to those who are in the informal sector and in responding to the main priorities: (1) Providing Emergency Assistance to Affected Sectors, (2) Securing Facilities [and] Resources for the Health Sector and (3) Performing Fiscal and Monetary Actions for the Economy.

\section{Civilians' role in the time of pandemic}

Giving meaning to the services of the government is the cooperation of the civilian in obeying those policies to fight this disease and prevent it from spreading (S3) as everyone's responsibility. Duterte stated that we are all soldiers in this war (S3) regardless of age, sex and socio-economic status. While everybody is doing his social obligation, the president expressed that his is to somehow protect and help Filipinos in distress (S4). In the end, he emphasized that nothing is more important [now] than one's cooperation. Along with this civilian' responsibility is the president's warning in case people would not follow, abuse their freedom or provoke the authority. Accordingly, the community personnel could bring them to police precinct for record purposes only in case uncooperative behaviour happens including those who are involved in hoarding and profiteering that affect the prize of the commodities (S6).

\section{Social distancing as human responsibility}

Social distancing becomes the keyword of his speeches, but on top of that, is the human responsibility to immediately cooperate to the call of the government in defeating the disease. He said, "yungdistansyamo to the other fellow, medyomalayo" (your distance with others must be far) and this is for the common good of everyone and not for the government (S2). This practice is an matter of protecting the public interest and public health and defending everyone from COVID-19; hence, it has nothing to do with the power of the military or the power of the police (S2). To observe this, the freedom of movement is curtailed, works in public and private sectors shall be limited to a work-at-home arrangement, and establishments that provide basic necessities and services will be open(S3) like restaurants and eateries.

\section{Frontliners' Heroism}

Short but worthy to emphasize, the president described the medical practitioners as heroes and even if they were no longer physically here on earth (S5), the president has so much respect to them with whom Filipinos will forever be grateful. In his March 30, 2020's address, he described them to be lucky and honoured to end life for the country; after all, dying in service for the country should be the reason of death. With the hard times that globally attack human lives, Duterte left consoling words not to be afraid (S2) because he is confident that everyone will emerge triumphant. While he honestly expressed that it is not easy, he embolden the people by saying that nothing is more formidable and resilient that the 
Filipino spirit because Filipinos are tough. It ended with entrusting the people that there is government who truly serves.

Using relational process, Duterte has provided the whole nation the individual's role to do; hence, it becomes clear for everyone to know and understand individualities in creating a stronger force against COVID-19. These appear on his discussion on the functions of the government to the people and vice versa. The study of Adjei \& Ewusi-Mensah (2016) on Kufour's farewell speech to the Ghanaian parliament also have a frequent use of relational processes as his way to clarify ambiguous concepts, to connect his political philosophies to that of his own for him to appear more acceptable to his audience as he built a very pleasing persona.

\section{Mental Process}

These processes show perception, affection and cognition where Senser serves as the conscious being that sees, wants, thinks, feels while the phenomenon is the sensed part of the clauses, the one that saw, wanted, thought and felt (Bustam, 2011). In this study, mental processes have the total frequency of 265 (19.33\%). In other words, mental processes support in linking the ideologies of the speaker to his people though emotional and mental appeal. Hence, the listeners would have the tendency to further understand the goal of the speaker as their inner activities are well-connected.

Analyzing the mental processes, it was revealed that these processes constructed clearly what the president thinks about the present condition, and what he hates about some beliefs and practices in relation to addressing the problem. Likewise, these processes helped build Duterte's hope and expectation of people's support especially the businessmen in extending their generosity to those who need most during the plight. These give a clear picture of what Duterte would like to happen in the period of this war against COVID-19 including his warning to those who caused conflicts.

\section{The president's wants and hopes}

In the president's fifth speech, he expressed his sadness over the number of medical doctors who become casualties of this virus causing him to deepen his appreciation to the frontliners to the kind of services they render. In his sixth speech, he assured that their heroism would be rewarded and would be not forgotten. With that, he continued to appeal to the public to follow the essential practices to stop the contagion even if he does not want to interfere (S2) in the enjoyment of Filipinos as he understands that the working force continues to spread the disease by saliva or by contact (S3). Accordingly, he does not want even that ordinary people to be confronted by the police or the military only because of their defiance. In his last speech, however, he said that if people want trouble, it should not be during this period of crisis. 
While he does not want to add additional tasks to the LGUs because of their already loaded responsibilities, there was no other choice but to give everyone an obligation as part of the working team to win the battle. Along with his gratitude to the local leaders is his warning to seriously do their obligations as elected officials. Addressing again the public, he hopes that people can understand what they are doing (I hope you can understand us (S4) as he knows that they really want to follow to help primarily themselves and their families. Showing his care, Dutertehas appealed to the big corporation to and business tycoons to respond to his call of support like considering the early release of their $13^{\text {th }}$ pay to their employees as a sign of their solidarity in this critical time. In relation, he urged business leaders to find ways to help business and ease the burden which is felt by the ordinary citizens (S3). On March 30, 2020, he implored those fortunate people in the private sectors to take care of the underprivileged by sharing what they have to keep solidarity. He also wants to see that the affected employees are properly taken care by their management (S2). Happily, he stated that there quite a number already who have expressed their willingness to partner with the government in this time of crisis (S3).

Mental processes are also contributory in building Duterte's connection to the people when he assures that Filipinos will feel that care and love of and from the government even if not everyone loves this government (S3). With the latest support of both House of Congress to his administration by providing him emergency power, he assured the following: the entire government is working hand-in-hand to safeguard people's health, safety and well-being in the face of the threat, protection of all the people especially those who are serving in the frontlines, and the government will be on top of the situation at all times (S5). To solidify these assurances, the president emphasized that he does not want red tapes (S5) with the following statement: Our transparency, integrity, accountability and responsiveness are needed and I expect all of you to exercise all these in safeguarding our fellow Filipinos. (S5)

Ending these is his encouragement people not to surrender and to be afraid as he looks forward to the day that Filipinos can finally claim victory [in] this war and emerge as a stronger and more united Filipinos and Philippines (S5) as he solemnly urges everyone to pray to the Almighty God who has the power to defeat every enemy, visible or invisible.

Mental processes, being among the most commonly employed processes in the transitivity system as appeared in many studies, have also shown its effective way for the president to build stronger relation with the people as he constantly showcased his human emotion to them: his care, his love and his understanding behind his tough way of handling the problem. With that, people would have an easier way to submit themselves with the kind of difficulties that are embodied in those orders and policies. No doubt, mental processes help speakers like any politician to deliver what they believe, thought and feel for their agenda, policy and ideology to be connected to what people expect Sharififar \& Rahimi (2015), by letting them feel that what has been stated is fact to establish persuading discourse (Liping, 2014).

\section{Verbal Process}


In this study, verbal processes have a total of 93 or $6.78 \%$, a little closer to existential but remains low as compared to other processes. The extracted samples of these processes consist of the Sayer (speaker) and the Receiver together with the Verbiage. In simple sense, verbal processes show how oral communication works where a message is created by the speaker for the purpose of sending it to the target audience or receiver who will process the message. Common verbs used weresay, said, tell, told, ask, asked, utter, uttered and the like.

In the analysis made, verbal processes are produced through Duterte's messages in a form of order, appeal, request and gratitude to various agencies down to the ordinary Filipinos. Likewise, statements and questions were also produced by other Sayers as participants like government officials and ordinary Filipinos.In his seventh speech, he has produced a stronger message to those who would cause conflicts that would threaten the purpose of the lockdown. The following are some of his messages to the specified people:

To the businessman and private individuals, please help. (Kaya akonakikiusapsamalalakingnegosyo, magtulongnalang kayo) (S3); slow down ... tone down your business or if possible stop (S3). His gratitude was expressed for their compassion and generosity $(S 6)$ as these are needed in times like this. To the producers of medical supplies, ensure the speedy delivery of basic medical supplies and equipment to health facilities (S5).To the LGU, no LGU should say that they only follow or allow food or essential goods to come in (S4); let us move forward together with one accord, implement the lockdowns, and save our people from the dreaded disease (S4) A province quarantine is advised when there are at least two positive COVID-19 cases belonging to different municipalities, component cities or independent component cities in the same province (S2). He has also extended his gratitude to the LGUs for their effort to contain the spread of the virus in their respective localities (S6).

To the military personnel, you can be there and ask for accommodation at pagkain(food) (S4); you have to implement this (S2); you will maintain order if things deteriorate. To farmers and fishermen, the government provides quick response measures to help you and to ensure food productivity, availability, and sufficiency (S6). To the public, we have seriousness problem (S7), obey the police and the military; wag kayongmatakot(don't be afraid); do not panicthat is a disturbance of the public order; follow the police; may peratayo (we have money); huwagkayongmasyadong ma-stress naparanghindimonamagawaang gusto mong gawin(don't be affected by stress so much that you can no longer do what you want to do); do not kill yourself with worry because the government is doing everything possible to make it at least controllable. Additionally, he ensures that there is unhampered flow of cargo and their workers to maintain the continuous and steady supply of food, goods and other essential supplies and items (S6). In his seventh address, he strongly stated that he hesitate to "shoot" those leftists who are causing conflict with the government in this period of crisis.

In his speech, he had never forgotten China and its government especially to President Xi Jinping with his short but effusive statement of gratitude, "Salamat" (S2) for the offered the later has made in case the situation gets worse in the Philippines. Eventually, he appealed 
again to the entire country to participate in this war by following the guidelines set by the national government and your local officials; to stay at home; and to have patience, understanding and utmost cooperation (S5). All throughout his speeches, he had never missed extending his thanks to the Filipino people with great emphasis to all frontliners especially the doctors, nurses, medical technologists and other allied health professionals, civil servants, officials and staffs of the Inter-Agency Task Force on Emerging and Infectious Diseases, brave men and women of the Armed Forces of the Philippines and the Philippine National Police, House of Congress, and other frontliners who continuously serve like those who works in government offices, groceries, banks, food establishments and delivery services, Salamatpo(Thank you), Maramingsalamatpo(Thank you very much), Nagpapasalamatpoakosainyonglahat(I am expressing my gratitude to all), we shall express our gratitude in a more tangible way when the crisis is over(S3)and DanghangSalamat (S6). Behind this is his warning to those people who will get involve in anomalous practices especially involving money which is intended for the public by saying that he would detain them and be released after the crisis.

\section{To the left: 'Shoot them dead'}

During his $7^{\text {th }}$ public address dated April 1, 2020, the usual Duterte has been seen on television when he angrily warned those people who are causing conflicts during the pandemic especially those who are leftist: 'shoot them dead' as they are not part of the government and cannot be a part of any undertaking to serve the country. Specifically citing Kadamay, an urban poor civil group, he said that no more consideration nor compassion would be given to them because of the direct disobedience to executive order on community quarantine as the president needs to set an example to everybody critically to preserve order. Intensifying this order is his assurance that he would protect any police officer who will follow his order in case of civil disobedience especially those who do harm to the frontliners. While verbal processes do not appear as frequently as other processes such as material, relational and mental, these are significant for Duterte to appear intimate to the audience or listeners. With such approach, it would be inferred that people might feel the personal connection of the president to them making it easier for the message to be easily materialized and accepted.

In another study on Duterte's speech, Salvaleon (2018) identified that the verbal processes in highlighting his top agenda and policies especially on war against illegal drugs and his support to the law enforcers which appeared in both direct and indirect discourse. However, most of analysed messages (verbiage) appeared to be unpleasant especially to the women; contrary to Churchill's verbal use which are "friendlier and more acceptable to the audience" (Liping, 2014, p. 135).

\section{Existential and Behavioural Processes}


Existential processes are the processes of existing which imply that something exists of happens. With there as the usual introduction, the verbs are usually in the form of be with the existent that completes the clauses. On the other hand, behavioural processes lie between material and mental processes that cause confusion; however, to put a distinction, behavioural process has only one participant unlike the others with "inseparable and indispensable" physical and mental qualities (Bustam, 2011). In the present study, existential processes has the frequency of $77(5.62 \%)$ while behavioural landed in the lowest frequency of only 15 or $1.41 \%$.

From those five speeches Duterte delivered, existential processes are formed through the statements of emphasis on the status of the virus and the community with the following existents: no cure, a case, a crisis without no solution in sight, a crisis that engulfing the country right now (S2), a slowdown in contagion, a danger (S3), confusion and chaos because of this lockdown. (S4)

Hence, the government assured that they are working to address the issue: mga skeletal (skeletal - a few employees, volunteer or selected); sufficient food, a set of rules governing the responsibilities of a Filipino citizen, no struggle of power, walang away dito, walanggiyera (no trouble, no war), a peace, order in the country, city health, provincial health, a structure, a vaccine by the grace of God (S2), a need for you to work with the government, no hunger in the coming weeks, changes in the structure, no interaction now, no trade to speak of, no flights going out, in, no need to be talking about it publicly, at least an economy working around, cases which we need to be attended to, no invasion, no rebellion(S3), power and audit (S6), work, no business, no order, distribution, and people (S7).

Behavioural processes do not play influentially in building Duterte's ideology in the analysed speeches. Most of the behavioural processes include kagatin (bite), nag-ubo (cough), humatsing (sneeze), sikma (blow one's nose), sigaw-sigaw (shout),bleeds and walk. In this study, both existential and behavioural processes appear to have less implication to the listeners. Although seldom used by many speakers in their speeches, Trump employed behavioural, together with verbal as a call to the Americans to uphold and exercise their rights; existential supports in presenting the real condition of the American society (Zhu \& $\mathrm{Li}, 2018)$.

\section{Conclusion and Suggestion}

Like many other studies on critical discourse analysis of politician's speeches, Duterte's public discourses on the precautionary measures of the government in fighting COVID-19 prove that his power, ideologies and policies are constructed and delivered through transitivity system of Halliday and Matthiessen $(2004$; 2014) where material, relational and mental were among the dominant processes that support the speaker to effectively achieve his goals. Through material processes, Duterte released his executive orders having the 
dominance of physical action involving the inclusive guidelines especially on social distancing and home and community quarantine. Likewise, the active movement of the government and even the private sectors solidly show how Duterte wanted to fight the battle. Similarly, relational processes are supportive as well in describing or in defining the functions that everybody should do as his contribution in winning the said fight. Mental processes, as well, work effectively in building the connection between the president and the target audience or listeners using mental and emotional appeal. True enough, this paper shows that President Duterte emphasizes his actions, clarity of description and emotional appeal work meritoriously in showing his power as the head of the nation. Undoubtedly, this analysis heavily claims that the manipulation of the language and its strategic application can build one's ideology and power through public discourse.

\section{Conflict of Interest}

The author of the article declares no conflict of interest.

\section{Funding}

This research study was not funded by any institution. The author conducted the study on his own expenses.

\section{References}

Adjei, A.A. \&Ewusi-Mensah, L. (2016). Transitivity in Kufour's 2008 farewell speech to the Ghanaian parliament. British Journal of English Linguistics, 4(1), 36-49.

Adjei, A.A., Ewusi-Mensah, L. \&Okoh, H. (2015). Transitivity in political discourse - A study of the major process types in the 2009 state-of-the-nation address in Ghana. Journal of Literature, Languages and Linguistics, 16, 23-32.

Ahmed, S., et al. (2014). A critical discourse analysis of Pakistani and Indian budget speeches. International Journal of Linguistics, 6(3), 141, 153. doi:10.5296/ijl.v6i3.5334.

Alvi, S. D. \&Baseer, A. (2011). An investigation of political discourse of Obama's selected speeches --- A Hallidian perspective. International Journal of Humanities and Social Science, 1(16), 150-160.

Balog, P.S. (2019). Transitivity analysis of selected privilege speeches of Senator Miriam Defensor-Santiago. Asian Journal of English Language Studies, 7, pp. 43-65.

Bustam, M.R. (2011). Analyzing clause by Halliday's transitivity system. JurnalIlmuSastra, 6(1), 22-34.

European Centre for Disease Prevention and Control: An agency of the European Union (25 March 2020). Retrieved from https://www.ecdc.europa.eu/en/novelcoronavirus/event-background-2019 (April 8, 2020).

Chaerunnisa, A. \&Dewi, H.D. (2019). How Duterte states his view on the Philippines and other countries relation: A discursive strategy analysis. JEELS (Journal of English 
Education and Linguistics Studies), 6(2), 215-240. doi: https:doi.org/10.30762.jeels.v612.1271.

Dacay, A.E. (2018). Speeches of President Rodrigo RoaDuterte: A critical discourse analysis. Tin-aw, 2(1). Retrieved from http://ejournals.ph/form/cite.php?id $=13565$

Dimaculangan, N.G. \&Dimaculangan, M.C.D. (2018). Hegemony in Pnoy's and Duterte's 1st State of the Nation Address: A critical discourse analysis of person deixis. JATIJournal of Southeast Asian Studies, 23(2), 152-180.

Fawcett, R. P. (n.d.). Invitation to systemic functional linguistics: The Cardiff Grammar as an extension and simplification of Halliday's Systemic Functional Grammar ( ${ }^{\text {nd }}$ ed.). Cardiff (UK): Center for Language and Communication Research, Cardiff University.

Fontaine, L. (2013). Analysing English grammar: A systemic functional introduction. New York: Cambridge University Press.

Goddard, A. \& Carey, N (2017). Discourse: The basics. New York: Routledge.

Halliday, M. A. K. and Matthiessen, C.(2004). An introduction to functional grammar ( $3^{\text {rd }}$ ed.). London: Edward Arnold.

Halliday, M.A.K., \&Matthiessen, C. (2014). An introduction to functional grammar (4th ed.). New York: Routledge.

Isti'anah, A. (2014). Transitivity analysis in four selected opinions about Jakarta governor election. Phenomena, 14(2), 163-175.

Janks, H. (1997) Critical Discourse Analysis as a Research Tool. Discourse: Studies in the Cultural Politics of Education,18(3), 329-342. doi:10.1080/0159630970180302.

Khalifa, R. (2018). A deictic analysis of the political discourse of some of Donald Trump's presidential speeches based on the discourse space theory. Sahifatul-Alsun Annual Refereed Journal, 34, 41-71.

Khanya, R. \&Hamzeloub, Z. (2014). A systemic functional analysis of dictators' speech: Toward a move-based model. Procedia - Social and Behavioral Sciences 98 / Elsevier, 917-924. doi: 10.1016/j.sbspro.2014.03.500.

Kondowe, W. (2014). Interpersonal metafunctions in BinguwaMutharika's second-term political discourse: A systemic functional grammatical approach. International Journal of Linguistics, 6(3), 70-84.

Liping, C. (2014). Experiential metafunctional analysis of Winston S. Churchill's speech on Hitler's invasion of the U.S.S.R. English Language Teaching, 7(9), 132-136. doi:10.5539/elt.v7n9p132.

McLeod, V. (16 March 2020). COVID-19: A history of coronavirus. Lab Manager (Retrieved from https://www.labmanager.com/lab-health-and-safety/covid-19-ahistory-of-coronavirus-22021, April 8, 2020).

Naz, S., Alvi, S.D. \&Baseer, A. (2012).Political language of Benazir Bhutto: A transitivity analysis of her speech 'Democratization in Pakistan'. Interdisciplinary Journal of Contemporary Research in Business, 4(8), 125-141.

Norgaard, N., Montoro, R., \&Busse, B. (2010). Key terms in stylistics. London: Continuum International Group.

Quijano, M.G. (2019). Metafunctions of the language used by three Philippine presidents: A critical discourse analysis. The Asian EFL Journal, 24(4.2), 39-63. 
Remorosa, R.R. (2018). President Rodrigo RoaDuterte's Political Speeches: A Critical Discourse Analysis. IOSR Journal of Humanities and Social Sciences (IOSR-JHSS), 23(8), 72-87. doi: 10.9790/0837-2308027287.

Salvaleon, R.G. (2018). Change is coming: A critical discourse analysis of President Rodrigo RoaDuterte's State of the Nation Addresses. International Journal of Humanities \& Social Studies, 6(7), 132-141.

Sharififar, M. \&Rahimi, E. (2015). Critical discourse analysis of political speeches: A case study of Obama's and Rouhani's speeches at UN. Theory and Practice in Language Studies, 5(2), 343-349. doi: 10.17507/tpls.0502.14.

Stojičić, V. \&Momčilović, N. (2016). Verbal derivatives and process types in transitivity configurations of english and german clauses. FACTA UNIVERSITATIS Series: Linguistics and Literature, 14(1), 15-24. UDC 811.111:811.112.2]'36.

Wang, J. (2010). A critical discourse of Barack Obama's speeches. Journal of Language Teaching and Research, 1(3), 254-261. doi:10.4304/jltr.1.3.254-261.

Wodak, R. \& Meyer, M. (2016). Critical discourse studies: history, agenda, theory and methodology. In Wodak and Meyer's (Eds.) Methods of Critical Discourse Studies ( $3^{r d} e d$.). London: SAGE.

Zhang, Y. (2017). Transitivity analysis of Hillary Clinton's and Donald Trump's first television debate. International Journal of Applied Linguistics \& English Literature, 6(7), 65-72. doi: 10.11648/j.ijla.20180602.11.

Zhu, Y, \& Li, F. (2018). Transitivity analysis of American President Donald Trump's inaugural address. International Journal of Literature and Arts, 6(2), 28-34. 